\title{
IKT-ESZKÖZÖK HASZNÁLATA AZ ANGOL NYELVTANULÁSBAN A PARTIUMI DIÁKOK KÖRÉBEN
}

\author{
USE OF ICT TOOLS IN ENGLISH LANGUAGE \\ LEARNING AMONG HIGH SCHOOL STUDENTS IN \\ THE PARTIUM REGION
}

\author{
Ardelean Tímea Krisztina
}

\begin{abstract}
Knowledge of foreign languages and hence its teaching at all ages has always played a very important role in people's lives. For centuries, different methods have been used to learn and teach foreign languages, always with the tools available at that time, in school settings or even during private lessons. In the twenty-first century, with the spread and popularity of the Internet, digital language learning broke into a virtual learning environment. Learning more foreign languages has become increasingly important. Learning materials can be easily achieved and communication with peers and instructors make learning easier. Nowadays it is possible to learn a language on the mobile phone, which opens new perspectives on language learning, especially among the generation Z, who love using their mobile phones. Due to the situation caused by the COVID-19 coronavirus the use of ICT tools in everyday learning and teaching has become a necessity in formal education. The present study intends to address this issue, especially the use of ICT tools in English language learning among high school students in the Partium region at the beginning of the pandemic. The results show that students are positive about learning English with ICT tools or using them in English, but more in the field of informal learning. There is a need to receive guidance from teachers so that students can take advantage of these tools in formal learning as well.
\end{abstract}

Keywords: Foreign Language, Computer Assisted Language Learning, ICT tools, Partium

\section{IKT (Információs és Kommunikációs Technológiák) eszközök az oktatásban}

A 21. században fontos szerepet kaptak az IKT-eszközök az élet minden területén, így az oktatásban, tanulásban is. Az IKT-eszközök önmagukban nem elegendők egy sikeres oktatás eléréséhez, a tanári hozzáértés és útmutatás elengedhetetlen mindenhol a világon, még a legfejlettebb országokban is. A COVID-19 koronavírus okozta helyzet miatt a világ számos országában szembesültek azzal a ténnyel, hogy annak ellenére, hogy egy iskola jól fel van szerelve IKT-eszközökkel, az online oktatás és tanulás nem müködik minden esetben zökkenőmentesen. Schrum és mtsai. (2016) szerint annak ellenére, hogy 35 éve állítják, hogy a technológia átalakítja az amerikai osztálytermeket, és hatalmas pénzügyi befektetéseket von maga után, és az Egyesült Államokban az összes oktatási technológiai kiadás 2013ban 13 milliárd dollárra nőtt, az oktatási technológiák széles körben elterjedt, jól integrált felhasználása továbbra sem valósult meg - sem a tanárok, sem a diákok nem használják ki őket (Ertmer és OttenbreitLeftwich, 2010). Ennek a hiányosságnak talán a legmeghatározóbb indoka, Schrum és mtsai. (2016) szerint a szakmai fejlődés jelentős hiánya, amely felkészítené a tanárokat az osztálytermükbe beépített technológiák hatékony integrálására az oktatási gyakorlatba. A tanárok, a tanulók, a technológia és a támogató rendszerek közötti interakciók egyértelmüen összetett problémát jelentenek (Cox és mtsai., 
2013). Még a folyamatos felhívásokra is, hogy fokozott figyelmet fordítsanak a tanárok felkészítésére az oktatási technológiák alkalmazásának hatékony integrálására a pedagógiai gyakorlatban, a hangsúly elsősorban a hardver, a szoftver és az infrastruktúra beszerzésére irányult (Schrum és mtsai., 2016). A helyzet hasonló az Európai Unióban is, ahol hasonlóképpen sok fejlesztés történt az iskolák IKTeszközökkel való felszerelésében, de ezen eszközök tanításban való felhasználása még nem valósult meg teljes mértékben. Az Európai Unió 10 éve tette közzé az Unió digitális stratégiáját, amit lassan minden tagállam átvett és az ország helyzetének megfelelően átalakított (European Commission, 2010). Románia 2015-re dolgozta ki az ország digitális stratégiáját, annak gyakorlatba helyezése még folyamatban van (Strategia, 2015). A digitális tanulás és oktatás egyik legfontosabb feltétele a megfelelő infrastruktúra, azaz az internet-hozzáférés, különben a már meglévő, különböző gazdasági és társadalmi okokból származó, egyenlőtlenségeket tovább növelhetik. A Román Nemzeti Statisztikai Hivatal 2019es adatai szerint a lakosság 78,4\%-a rendelkezik szélessávú internettel, a városokban 85,5\%, vidéken $66,9 \%$, mobilinternettel pedig 64,2\%, városokban 62,4\%, vidéken 67,2\%. A COVID-19 koronavírus miatt kialakult helyzet rávilágított arra, hogy nagyon nehézkesen müködik az online tanulás és oktatás, és a fent említett hiányos infrastruktúra miatt az nem minden diák számára elérhető. Az IKT-eszközök és azon belül a közösségi média által nyújtott lehetőségek egyre inkább elötérbe kerülnek, amelyek immár a kapcsolattartás mellett a tanulást is elősegítik. Mivel egyik napról a másikra kellett átállni az online tanulásra és oktatásra, tömegesen tapasztalhatjuk meg annak előnyeit és hátrányait.

\section{Számítógéppel segített nyelvtanulás}

Chapelle (2010) szerint a számítógépes nyelvtanulás fogalma (Computer Assisted Language Learning, CALL) sokféle technológiai felhasználást tartalmaz, például CD-ROM-okat, szoftvereket, online referenciaanyagokat, elektronikus kommunikációs eszközöket és a közösségi médiát. Kern és Warschauer (2000) a számítógépes nyelvtanulás több mint ötven éves történetét nagyjából három különálló szakaszra osztják a nyelvoktatásban alkalmazott paradigmaváltások alapján: viselkedésbeli/behaviorista vagy strukturális számítógépes nyelvtanulás az 1960-as és 1970-es években, kognitív vagy kommunikatív számítógépes nyelvtanulás az 1980-as években és a szociokulturális, társadalmi-kognitív vagy integráló számítógépes nyelvtanulás az 1990-es évektől kezdődően. Az 1993 és 2009 közötti 350 tanulmány áttekintése (Golonka és mtsai, 2014) rámutatott arra, hogy a számítógépes nyelvtanulás hatékonysága korlátozottan bizonyított, és csak mérsékelten támogatta azt az állítást, hogy a technológia használata megváltoztatta a tanulás folyamatát. Bizonyos területeken (chat, számítógépes kiejtés és automatikus beszédfelismerés) erős bizonyítékot találtak a megnövekedett nyelvtermelésre, míg más területeken a mérsékelt támogatás megállapításai kvalitatív, önálló és megfigyelési adatokra épültek. Megállapítást nyert, hogy a tanulók élvezik a technológia használatát, hajlamosabbak elköteleződni a nyelvtanulás iránt és pozitívabban állnak a tanuláshoz.

\section{Célkitüzések, kutatási kérdések}

A kutatás célja feltérképezni a partiumi diákok IKT-használatát és véleményüket ezen eszközök alkalmazásáról általában és az angol nyelvtanulásban.

A kutatásban az alábbi kérdésekre kerestük a választ:

- Milyen mértékben és milyen célból használják a diákok az IKT-eszközöket és alkalmazásokat otthon, valamint az iskolán kívül?

- Milyen internethozzáféréssel rendelkezik az iskola, ahol a megkérdezett diákok tanulnak és milyen IKT-eszközöket és alkalmazásokat használnak tanulás céljából az órákon?

- Használnak-e IKT-eszközöket angol nyelvtanulás céljából otthon, az iskolán kívül, illetve az iskolában?

- Mi a véleményük az IKT-eszközökröl és azok használatáról általában véve és az angol nyelvtanulásban? 
Kutatási kérdéseink alapján a következő hipotéziseket fogalmaztuk meg:

H1. Feltételezzük, hogy a megkérdezett diákok otthon és az iskolán kívül nagy mértékben és gyakran használnak IKT-eszközöket és alkalmazásokat, föleg szórakozás és kommunikálás céljából.

H2. Feltételezzük, hogy a megkérdezett diákok az iskolában rendelkeznek internethozzáféréssel, valamint az IKT-eszközöket és alkalmazásokat nagyon kis arányban használják tanulás céljából az órákon.

H3. Feltételezzük, hogy a megkérdezett diákok használnak IKT-eszközöket és alkalmazásokat angol nyelvtanulás céljából otthon, az iskolán kívül, illetve az iskolában.

H4. Feltételezzük, hogy a megkérdezett diákok pozitívan vélekednek az IKT-eszközökről és azok használatáról általában véve és az angol nyelvtanulásban.

\section{Kutatási módszerek, eszközök}

A kérdőív összeállításához a LimeSurvey nevủ nyílt forráskódú alkalmazást használtuk. A LimeSurvey előre telepített környezettel és adatbázissal rendelkező kérdőíveztető motor. A program nagyon sokféle kérdéstípus beiktatására és elrendezésére alkalmas, melyek között feltételes kapcsolat is létrehozható. A kitöltött kérdőív eredményeit a program egy adatbázisban tárolja, amely adatsor kinyerhető MS Word, xls, csv, pdf, HTML vagy akár SPSS statisztikai formátumban is. A LimeSurvey az eredményekből grafikus diagramokat is tud készíteni, de azok nem olyan kidolgozottak, így az ábrákat az Excel alkalmazással végeztük el. A kérdőíveket online töltötték ki a diákok. A kérdőív elemzéséhez a leíró statisztikát választottuk (Griffith, 2010), mert úgy gondoljuk, hogy a kutatás célcsoportjáról gyüjtött adatok rendszerezésére és leírására ez a legalkalmasabb módszer. Ennek a módszernek a célja a minta adatainak áttekinthető formába történő rendezése, tömörítése, az adatok grafikus megjelenítése, ábrázolása és egyes jellemző értékeinek meghatározása. Az adatelemzéshez a PSPP, nyílt forráskódú szoftvert használtuk, ami az SPSS szoftver alternatívája.

\section{Kutatási minta és a kutatás terepe}

Jelen kutatás alapjául egy kérdőív szolgált, amit két partiumi megyében kérdeztünk le. Partium évszázadokig államigazgatási-közigazgatási egység volt a Kárpát-medencében, s ennek következtében olyan földrajzi-topográfiai név is lett, amelynek lakói - határainkon innen és túl - mind a mai napig használják ezt földrajzi tájnévként (Szilágyi, 2019). A napjainkban Partium néven emlegetett terület Románia északnyugati megyéit jelenti: Bihar, Szatmár, Szilágy, Máramaros és részben Arad megye területét (Szilágyi, 2019). A magyarság e vidéken legnagyobb számban Szatmár és Bihar megyében képviselteti magát. A magyar iskolákon kívül román, német, illetve többnyelvü iskolákat is vizsgáltunk. A kérdőívet Bihar és Szatmár megyei iskolákban töltötték ki kilencedikes és tizenkettedikes diákok online. Azért választottuk ezt a két osztályt, mert így vizsgálni lehet a diákok angol nyelvhez való viszonyát a gimnáziumba való bejutáskor és az utolsó évben kimenet előtt. A kérdőív tartalmát és a lekérdezés folyamatát több városban egyeztettük az iskolavezetőkkel, akik felhívták a figyelmet arra, hogy valószínűleg nagyon alacsony lesz a kitöltési arány, ha online küldjük el, ezért azt javasolták, hogy az informatika órák keretén belül legyen a lekérdezés. Személyesen részt vettünk volna a lekérdezésnél, és így egy nagyobb mintát vizsgálhattunk volna, de amikor erre sort kerítettünk volna, bezárták az iskolákat a COVID-19 koronavírus miatt kialakult helyzet következtében. Végül online töltötték ki a diákok az igazgatók által kiküldött kérdőívet. Beigazolódott, hogy online sokkal kevesebben töltötték ki, mint amire számítottunk. Összesen 36 iskolának küldtük ki a kérdőívet, és 10 iskolából jött válasz diákoktól. Az iskolák különböző tannyelvüek: magyar, román, német és vegyes.

A kérdőívet 244 diák töltötte ki, kitöltése anonim volt. A diákoktól kért adatok a következők voltak: nem, kor (betöltött években), nemzetiség, anyanyelv, anyanyelven kívül beszélt más nyelvek, iskola, osztály, az osztály profilja, az osztály tannyelve, lakhely, melyik megyében tanul, ingázik-e, az anya iskolai végzettsége, az apa iskolai végzettsége. Mivel sajnálatos módon nem valósulhatott meg a kívánt 
minta, a diákok adatainál több kérdésnél összevontunk válaszlehetőségeket, hogy az elemzés könnyebb és értelmezhetőbb legyen. A nemek szerinti eloszlás a válaszadó diákok között a következő: 168 lány és 76 fiú. A korukat tekintve a többség 14-15 éves, valamint 18-19 éves, mivel a kérdőívvel a kilencedikes és tizenkettedikes diákokat céloztuk meg. A középfokú oktatásba bemenő, illetve végzős diákok válaszaira épül a kutatás, azt vizsgálva, hogy van-e különbség az IKT-eszközök használata tekintetében e két kategóriánál. A nyelveket figyelembe véve négyféle iskolából voltak válaszadók, magyar, román, német tannyelvü, illetve vegyes tannyelvű iskolákból, ezért változóként bekerültek az anyanyelv, a nemzetiség és a beszélt nyelvek, hogy meg tudjuk vizsgálni, van-e összefüggés nyelvi szempontból a kutatott témával. A román gimnáziumi rendszerben sokféle profil létezik: elméleti humán - filológia; elméleti - humán - társadalomtudományok; elméleti - reál - matematika informatika; elméleti - reál - természettudományok; müszaki (elektronika, automatizálás, villamossági, energetika, számítástechnika, mechanika, elektromechanika stb.); szolgáltatások (idegenforgalom és élelmezés, gazdaság, kereskedelem, az emberi test esztétikája és higiéniája, egészségügy); természeti erőforrások és környezetvédelem (élelmiszeripar, mezőgazdaság, erdészet, környezetvédelem); teológia; mủvészet - képzőmủvészet; mủvészet - zene; pedagógia és sport. A könnyebb elemzés eléréséhez a válaszokban megjelölt profilokat is csoportosított formában került elemzésre. A válaszadók 64,34\%-a Bihar megyéből, 35,66\%-a Szatmár megyéből került ki. A kérdőívet kitöltő diákok 53,28\%a él városban, 46,72\%-a pedig falun vagy községben. Végül, de nem utolsósorban, fontosnak tartottuk megkérdezni a szülők iskolai végzettségét, ami szintén egy befolyásoló tényező lehet, ha bármilyen tanulásról beszélünk, így jelen esetben is mérvadó lehet.

\section{Az eredmények bemutatása}

Az első kérdésblokkban azt vizsgáltuk, hogy a diákok milyen mértékben használják az IKT (információs és kommunikációs technológiák) eszközöket az iskolán kívül. Arra a kérdésre, hogy: „Használsz számítógépet vagy laptopot/notebookot az iskolán kívül (pl. otthon, barátoknál, könyvtárban, internet kávézóban stb.)?” a diákok nagyon nagy része, 95,49\%-a azt válaszolta, hogy használ számítógépet vagy laptopot/notebookot az iskolán kívül. Ez az arány ebben a korosztályban alig marad alul az európai uniós átlaghoz képest, ami 97\% (European Commission, 2019). Az internethasználat napi, heti vagy több havi használata is átlagban 97\%-on van a válaszadók körében (1. ábra).

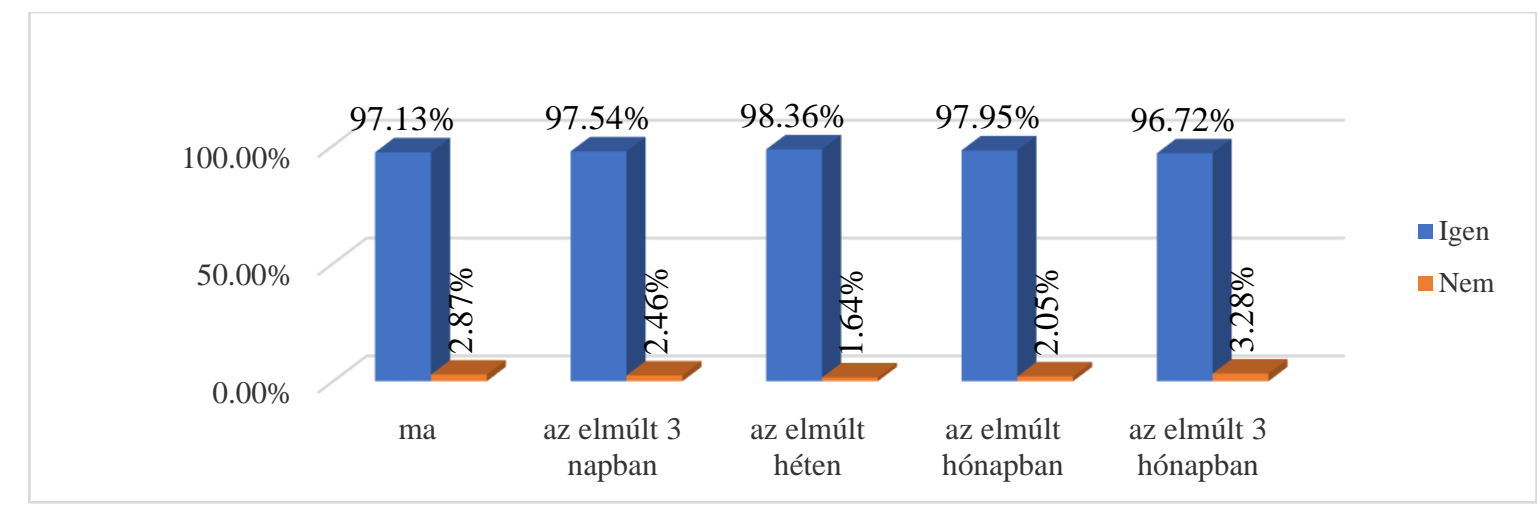

1. ábra. Használtad az internetet az iskolán kívül (pl. otthon, barátoknál, könyvtárban, internet kávézóban stb.)? $(\mathrm{N}=244)$

A válaszadó diákok otthoni vagy iskolán kívüli IKT-eszközhasználatáról (2. ábra) megállapíthatjuk, hogy nagyon nagy mértékben az okostelefonra és a laptopra korlátozódik. A válaszadók fele rendelkezik otthon asztali számítógéppel internetes hozzáféréssel, de a laptop $(57,38 \%)$ és az okostelefon $(64,75 \%)$ használata a leggyakoribb körükben otthon és az iskolán kívül. 


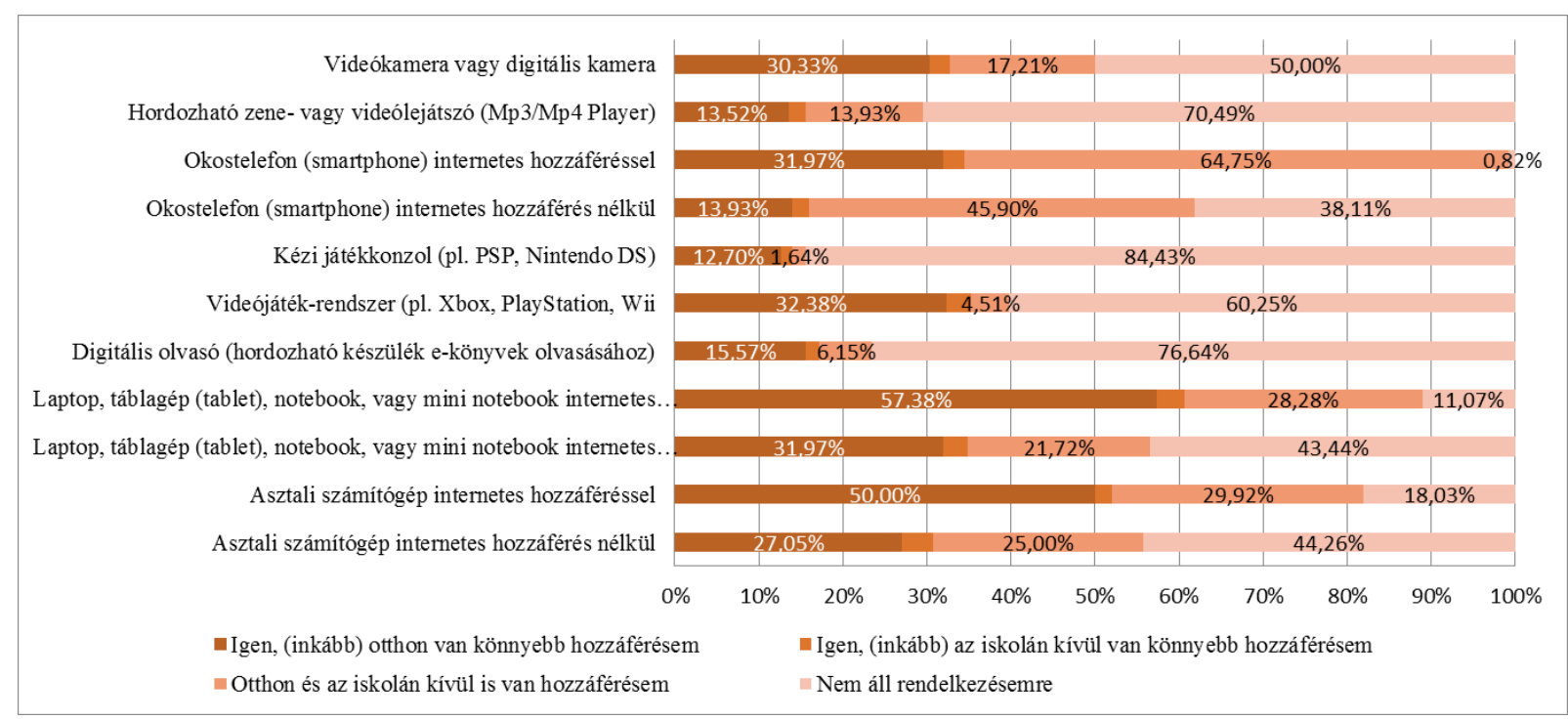

2. ábra. Az alábbiak közül melyikhez van könnyü hozzáférésed otthon vagy az iskolán kívül (pl. barátoknál, könyvtárban, internet kávézóban stb.)?

Arra a kérdésre, hogy: „Hány éve használsz számítógépet otthon vagy az iskolán kívül?” (3. ábra) a válaszadók többsége, $63,11 \%$-a mondta, hogy több mint 6 éve. Ez a nagy arány várható volt, hiszen a megkérdezettek a Z-generáció tagjai, akik gyerekkoruktól kapcsolatban vannak az információs és kommunikációs technológiákkal.

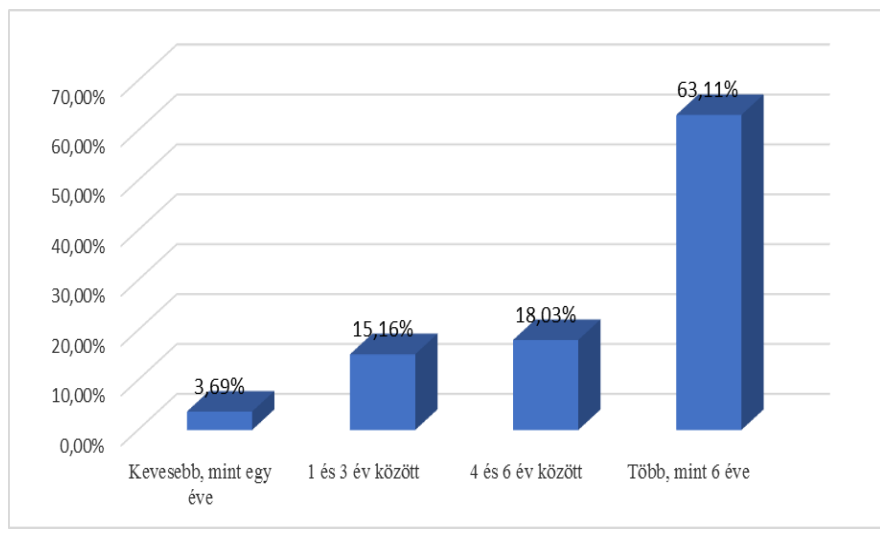

3. ábra. Hány éve használsz számítógépet otthon vagy az iskolán kívül?

A blokk utolsó két kérdése arra irányult, hogy a diákok a szabadidejükben milyen gyakran végzik a felsorolt tevékenységeket, amik a közösségi médiához kötődnek (4. és 5. ábrák). 


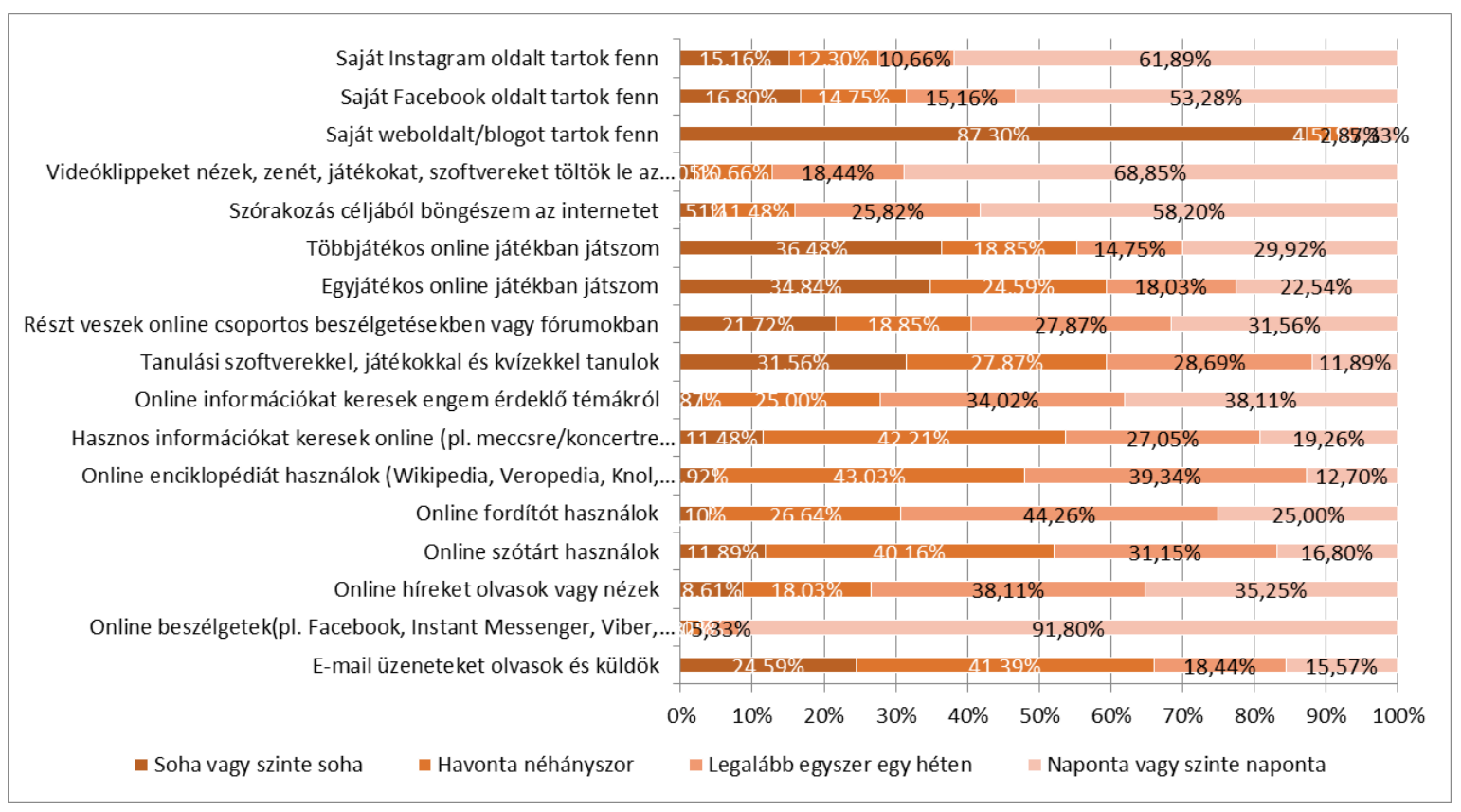

4. ábra. Szabadidődben milyen gyakran veszel részt az alábbi tevékenységekben otthon vagy az iskolán kívül?

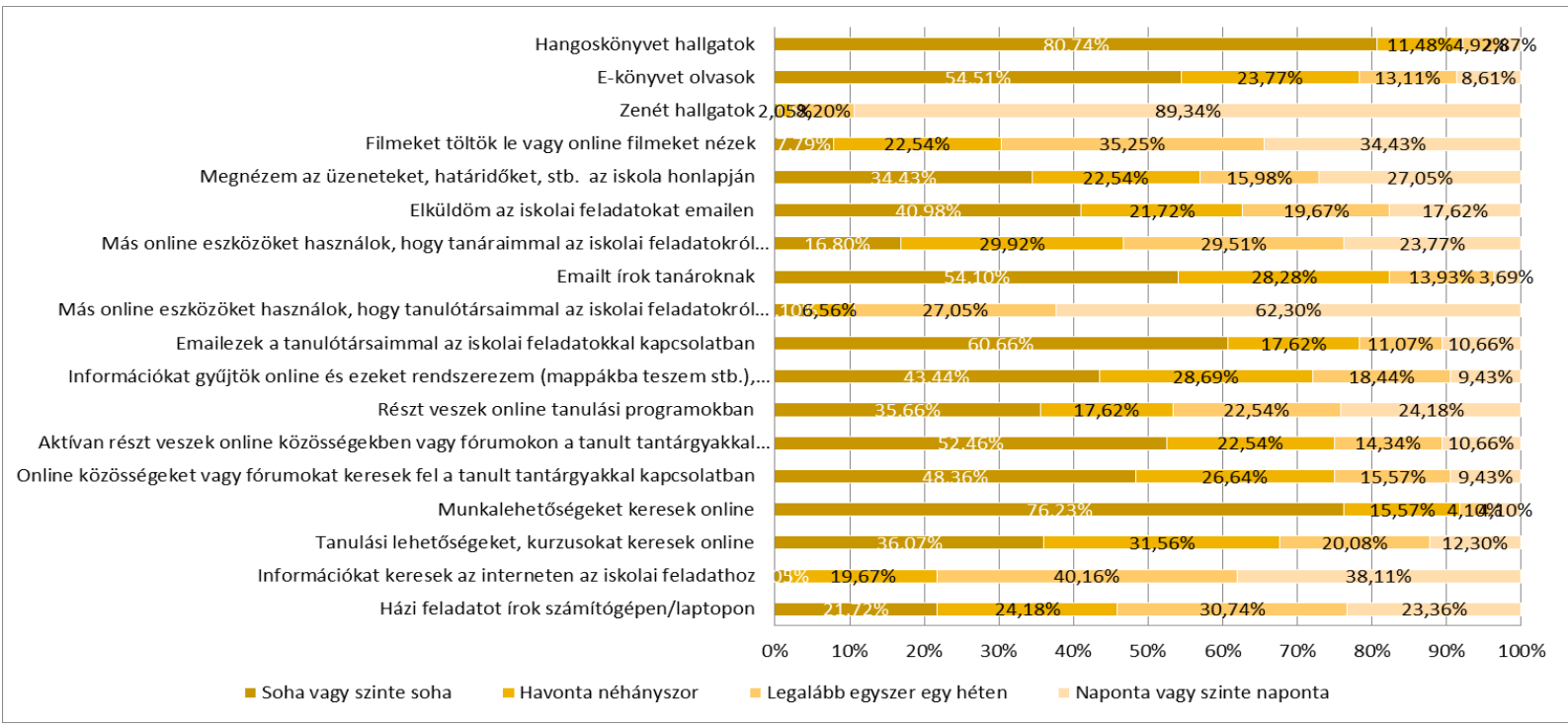

5. ábra. Milyen gyakran végzed a következö tevékenységeket otthon vagy az iskolán kívül?

Az eredmények azt mutatják, hogy a válaszadó diákok napi vagy szinte napi szinten végzik a következő tevékenységeket: online beszélgetnek pl. Facebook, Instant Messenger, Viber, WhatsApp-on (91,80\%), zenét hallgatnak (89,34\%), videóklipeket néznek, zenét, játékokat, szoftvereket töltenek le az internetről (68,85\%), szórakozás céljából böngészik az internetet (58,20\%), más online eszközöket használnak, hogy tanulótársaikkal az iskolai feladatokról beszéljenek pl. Instant Messenger, Facebook, Viber, WhatsApp-on $(62,30 \%)$, saját Facebook oldalt tartanak fenn $(53,28 \%)$, saját Instagram oldalt tartanak fenn $(61,89 \%)$, filmeket töltenek le vagy online filmeket néznek $(34,43 \%)$, információkat keresnek az interneten az iskolai feladathoz $(38,11 \%)$. Legalább egyszer egy héten online fordítót használnak (44,26\%), online enciklopédiát használnak, pl. Wikipedia, Veropedia, Knol, Interpedia, Wikia stb. $(39,34)$, online híreket olvasnak vagy néznek $(38,11 \%)$, online információkat keresnek őket érdeklő témákról (34,02\%), házi feladatot írnak számítógépen/laptopon (30,74\%). Soha vagy szinte soha nem tartanak fenn weboldalt/blogot $(87,30 \%)$, nem hallgatnak hangoskönyvet $(80,74 \%)$, nem keresnek munkalehetöségeket online (76,23\%), nem e-maileznek a tanulótársaikkal az iskolai feladatokkal 
kapcsolatban (60,66\%), nem írnak e-mailt tanároknak (54,10\%), nem olvasnak e-könyveket $(54,51 \%)$. Az eredmények tükrében az első hipotézisünk beigazolódott, miszerint a megkérdezett diákok otthon és az iskolán kívül nagy mértékben és gyakran használnak IKT-eszközöket és alkalmazásokat, föleg szórakozás és kommunikálás céljából.

A második kérdésblokkban a diákok válaszaiból kiderül, hogy az iskolák, ahova járnak, többféle internethozzáféréssel rendelkeznek (6. ábra), valamint a tanulók 76,64\%-a már használt számítógépet, táblagépet (tablet), laptopot/notebookot tanulás céljából az iskolában.

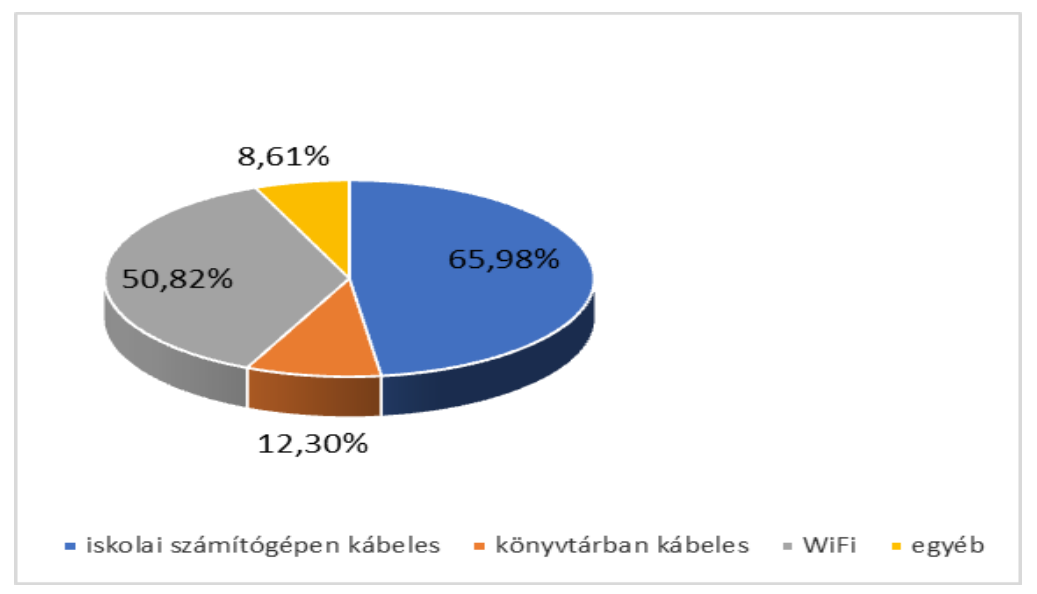

6. ábra. Internethozzáférés az iskolában

A kérdésblokk utolsó két kérdése az eszközök és alkalmazások használatára kérdez rá tanulás céljából az órákon, valamint azok használatának gyakoriságára. A második hipotézisünkben az IKT-eszközökkel és alkalmazásokkal kapcsolatos feltevésünk részben igazolódott be, hiszen azokat kis arányban használják a diákok tanulás céljából az órákon, kivételt képez a mobiltelefonok használata. A diákok napi szinten a következő eszközöket és alkalmazásokat használják: saját mobiltelefon (56,56\%), saját laptop vagy notebook $(15,57 \%)$, közvetítőeszközök, broadcasting pl. podcast közzététele, YouTube videók feltöltése stb. (12,70\%), asztali számítógép internetes hozzáféréssel (16,80\%). Ebből a felsorolásból is látszik, hogy a mobiltelefonok használata nagyon gyakori, és nagy arányban használják tanulásra is az eszközt. A „legalább hetente egyszer” válaszlehetőségre a diákok a következőket jelölték meg: asztali számítógép internetes hozzáféréssel (37,30\%), multimédia szerkesztési eszközök pl. PowerPoint, videószerkesztők, digitális felvevők (36,89\%), saját mobil (23,77\%), gyakorló szoftverek, online kvízek és tesztek (22,13\%). A legtöbb válasz a soha vagy szinte soha válaszlehetőségre jött, ami arra utal, hogy a legtöbb diák nem gyakran használja az említett eszközöket és alkalmazásokat. A diákok a mobiltelefon mellett a számítógépet vagy laptopot használják az órákon leggyakrabban, ezért ezzel az eszközzel végzett tanulási tevékenységekre is rákérdeztünk, hogy egy összetettebb képet kapjunk az eszközhasználatról. Számítógépen vagy laptopon, napi szinten tanulás céljából a következö tevékenységeket jelölték meg (7. ábra): online beszélgetek iskolai dolgokról pl. Facebook, Instant Messenger, Viber, WhatsApp, stb. (26,64\%), Böngészem az internetet, hogy információkat gyüjtsek (26,64\%), Használom a számítógépet a feladatok elvégzéséhez pl. adatok/képek gyüjtéséhez, ezek tárolására, észrevételek dokumentálására stb. $(19,26 \%)$. A „soha vagy szinte soha” válaszlehetőségre a legtöbb válaszadó a következőket választotta: Részt veszek vagy létrehozok blogokat, fórumokat az iskolai feladatokhoz $(79,10 \%)$, Más felületekre töltök fel tartalmakat vagy osztok meg tartalmakat (62,30\%), Részt veszek online képzéseken $(59,84 \%)$, Részt veszek tanulási témámmal kapcsolatos online közösségek fórumain $(56,15 \%)$. 


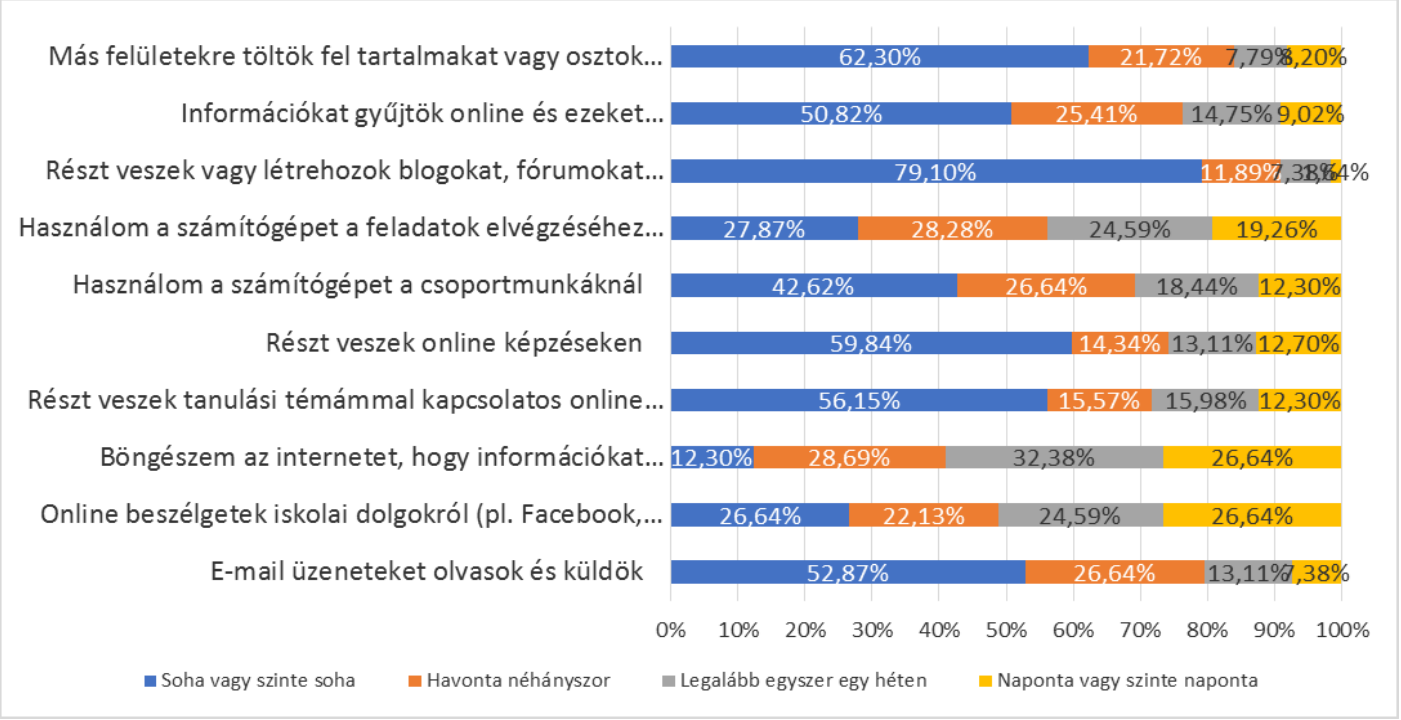

7. ábra. Milyen gyakran használsz számítógépet/laptopot az alábbi tanulási tevékenységekhez az órák alatt?

A kutatás szempontjából a harmadik kérdésblokkban szereplő kérdésekre érkezett válaszok a leglényegesebbek, mivel azok az angol nyelvtanulási célú internet- és közösségi média használatra vonatkoznak. Romániában a legtöbb esetben a középiskolai diákok az angol nyelvet tanulják első idegen nyelvként, és ez tükröződik a kérdőívre jött válaszokban is, mivel 98,77\% válaszolta azt, hogy tanul angolul jelenleg. A heti óraszámokat tekintve átlagban majdnem 3 angol órájuk van. Arra a kérdésre, hogy „Hány órát használsz különböző mobilos alkalmazásokat nem tanulási célokra angol nyelven egy héten?" (8. ábra) csak 10,66\% válaszolta azt, hogy nem használ angol nyelvü alkalmazásokat. A legtöbben 1-2 órát használnak $(27,46 \%)$, de 14,34\%-a a válaszadóknak hetente akár 16-20 órát is használ különböző mobilos alkalmazásokat nem tanulási célokra angol nyelven.

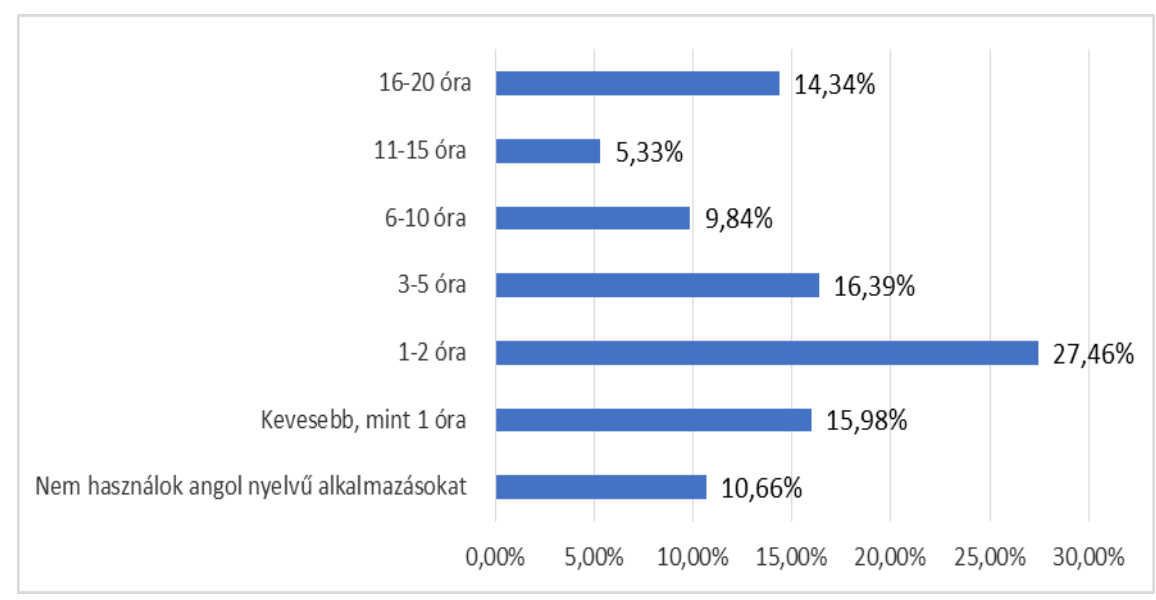

8. ábra. Hány órát használsz különböző mobilos alkalmazásokat nem tanulási célokra angol nyelven egy héten?

A leggyakoribb tevékenységek, amelyekhez az angol nyelvet használják (9. ábra), a következök: Letölteni vagy online hallgatni zenét (78,69\%), Mobiltelefonon játszani $(67,62 \%)$, Letölteni filmeket vagy online filmeket nézni $(67,62 \%)$, Hírek olvasása az interneten $(49,18 \%)$, Saját Facebook oldal megtekintése (41,39\%). Csak 4,10\% válaszolta azt, hogy egyik felsorolt tevékenységet sem végzi angol nyelven. 


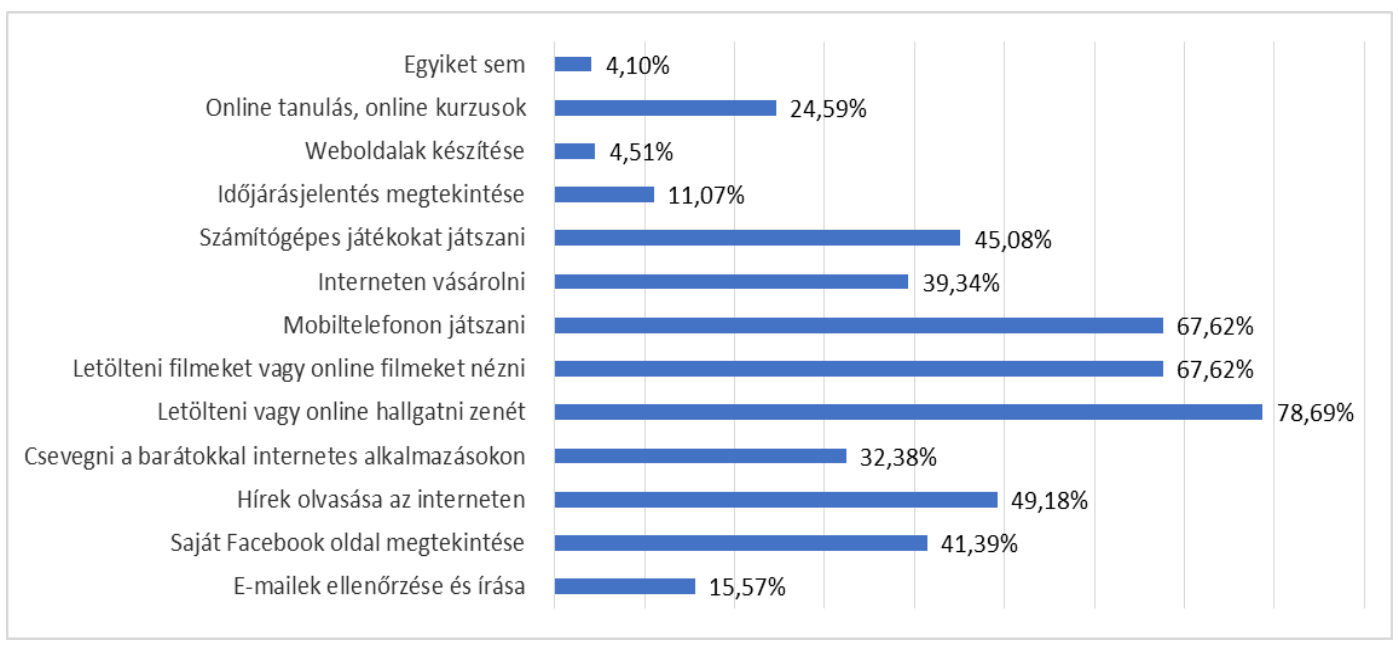

9. ábra: Az alább felsorolt tevékenységek közül melyikhez használod az angol nyelvet?

Kifejezetten angol nyelvtanulás céljából (10.ábra) a következők lehetőségeket használják az interneten: Google fordító $(82,79 \%)$, online szótár $(60,66 \%)$, Feladatok megbeszélése barátokkal közösségi hálózatokon angol nyelven pl. Facebook, Instant Messenger, Viber, WhatsApp, stb. (29,92\%). Ezúttal is elég elenyésző volt azon válaszadók száma, akik az Egyiket sem válaszlehetőséget választották.

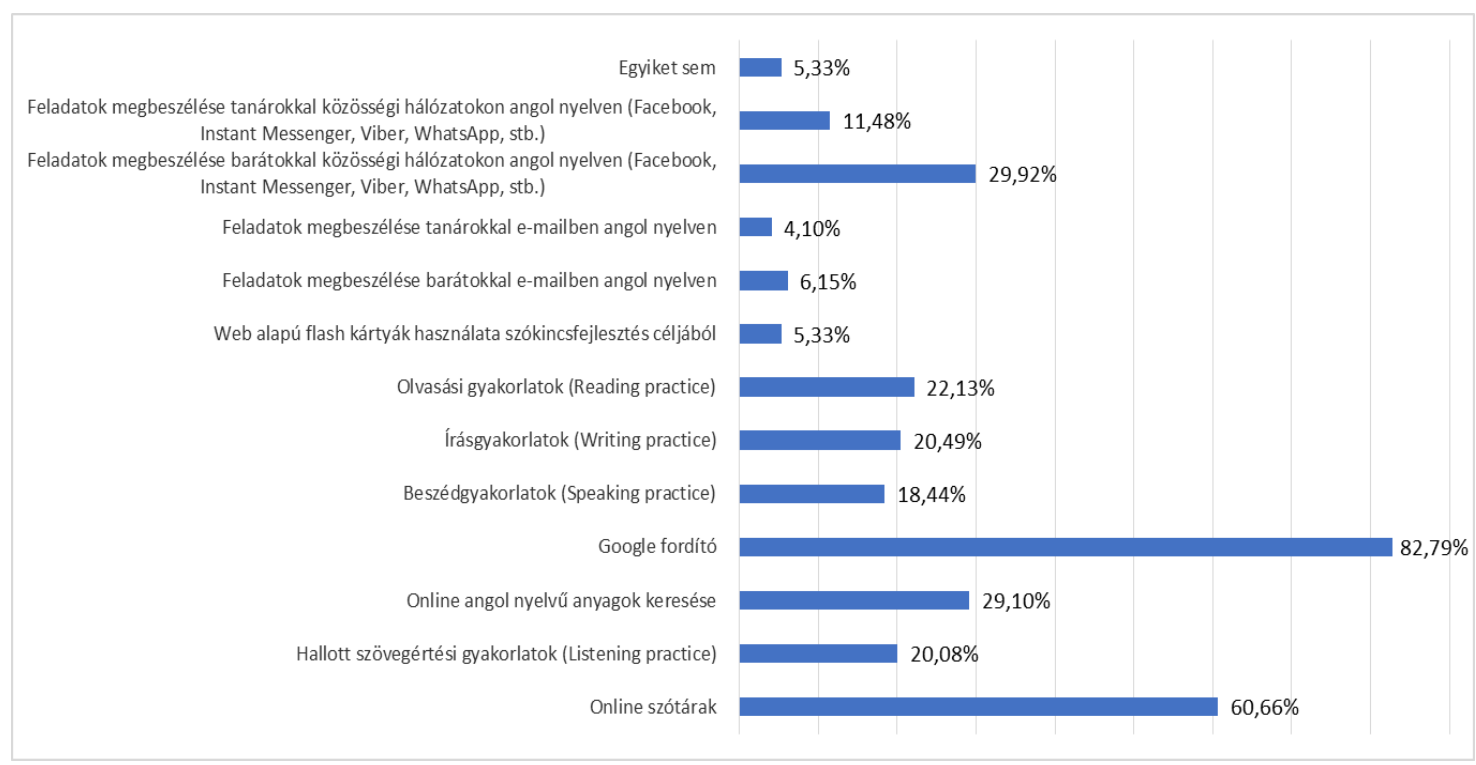

10. ábra. Az alábbi alkalmazások közül melyeket használod angol nyelvtanulás céljából?

A közösségi média platformok közül angol nyelvtanulás céljából az iskolában a legtöbben a YouTubet (63,93\%) használják (11. ábra), ezt követte a Facebook (32,38\%), Facebook Messenger (30,33\%), majd az Instagram $(28,28 \%)$. Megfigyelhetjük, hogy a megkérdezettek az összes felsorolt közösségi média platformot használták már az iskolában, és szinte mindegyiket nagyobb mértékben alkalmazzák otthon angol nyelvtanulás céljából. 


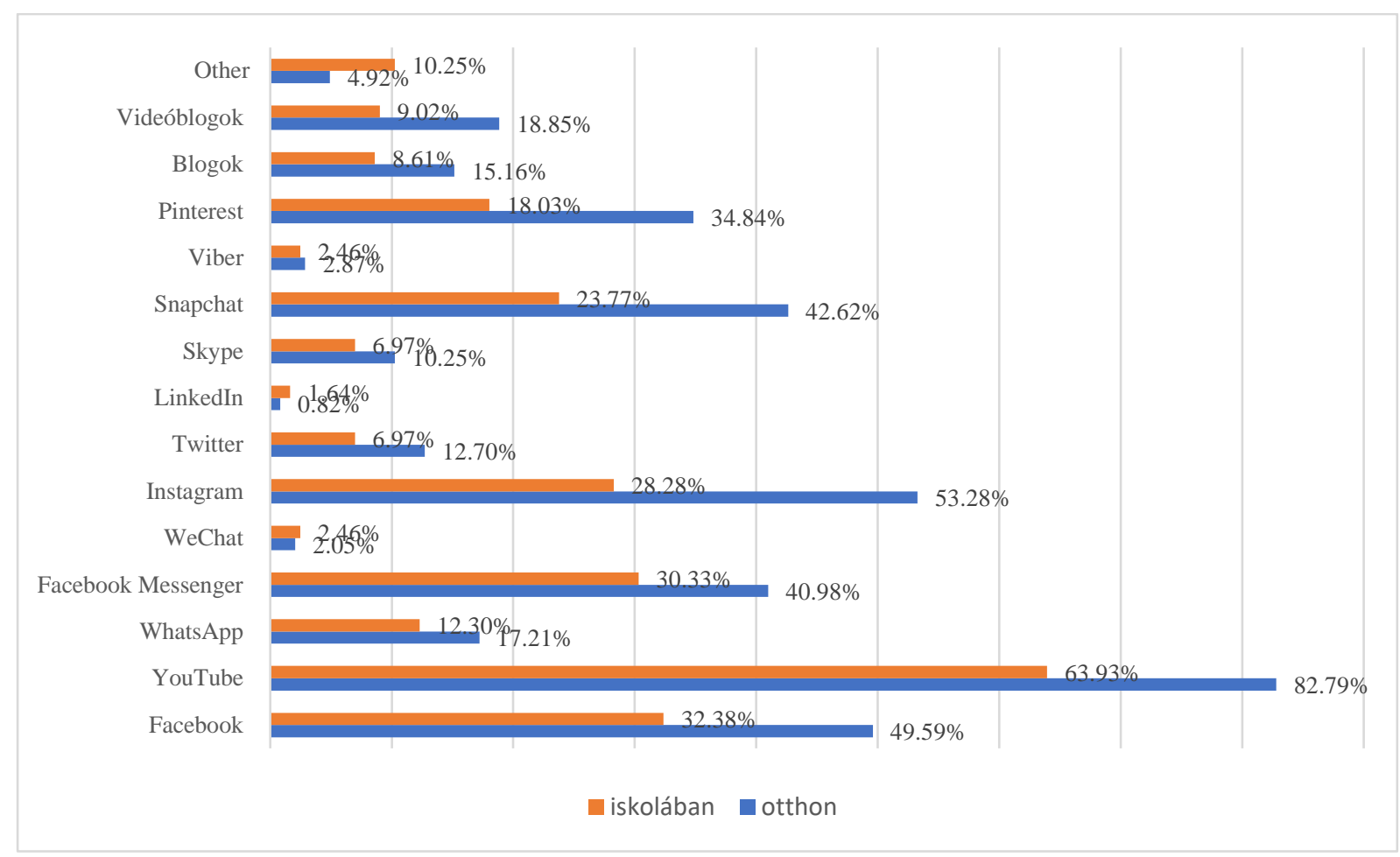

11. ábra. A felsorolt közösségi média platformok közül melyeket használtad már angol nyelvtanulás céljából az iskolában és otthon?

Ugyanerre a kérdésre, hogy a közösségi média platformok közül melyeket használta már angol nyelvtanulás céljából, de otthon vagy az iskolán kívül (11. ábra), hasonló válaszok érkeztek, de nagyobb arányban: Youtube (82,79\%), Instagram (53,28\%), Facebook (49,59\%), Snapchat (42,62\%). Ezáltal a harmadik hipotézisünk is beigazolódik, hiszen a megkérdezett diákok használnak IKT-eszközöket és alkalmazásokat angol nyelvtanulás céljából, nagyobb mértékben inkább otthon.

A kérdésblokk utolsó két kérdése a diákok véleményét kérdezte a közösségi média angol nyelvtanulásra vonatkozó aspektusairól és a tanárok szerepéről, valamint a közösségi médiával való tanításról (1. és 2. táblázat). Szinte minden pontnál több mint $50 \%$-a a válaszadóknak egyetértett a kérdésben megjelent kijelentésekkel, hogy például a közösségi média használata segít fejleszteni az angol nyelvi olvasási készségüket (Reading), bővíti az angol nyelvi szókincsüket (Vocabulary), fejleszti az angol nyelvi szöveghallgatási készségüket (Listening), valamint az angol nyelvtanulás sokkal szórakoztatóbb lehet a közösségi média alkalmazásokkal.

1. táblázat: A közösségi média használatához kapcsolódó vélemény (százalékban kifejezve)

\begin{tabular}{|l|c|c|c|c|c|}
\hline $\begin{array}{l}\text { Milyen mértékben értesz egyet az alábbi } \\
\text { kijelentésekkel? }\end{array}$ & $\begin{array}{l}\text { Egyáltalán nem } \\
\text { értek egyet }\end{array}$ & $\begin{array}{l}\text { Nem } \\
\text { értek } \\
\text { egyet }\end{array}$ & $\begin{array}{l}\text { Egyet } \\
\text { is értek } \\
\text { meg } \\
\text { nem is }\end{array}$ & Egyetértek & $\begin{array}{l}\text { Nagyon } \\
\text { egyetértek }\end{array}$ \\
\hline $\begin{array}{l}\text { A közösségi média (pl. blogok, a } \\
\text { videóblogok, a kép- és videómegosztó } \\
\text { oldalak, üzenőfalak, e-mail üzenetek, } \\
\text { üzenetküldỏ szolgáltatások és programok, } \\
\text { zenemegosztás) használata segít jobban } \\
\text { elsajátítani az angol nyelvet }\end{array}$ & $2,05 \%$ & $2,46 \%$ & $19,67 \%$ & $42,21 \%$ & $33,61 \%$ \\
\end{tabular}




\begin{tabular}{|l|c|c|c|c|c|}
\hline $\begin{array}{l}\text { A közösségi média használata segít fejleszteni } \\
\text { az angol nyelvi olvasási készségemet } \\
\text { (Reading) }\end{array}$ & $2,05 \%$ & $2,46 \%$ & $13,93 \%$ & $46,72 \%$ & $34,84 \%$ \\
\hline $\begin{array}{l}\text { A közösségi média használata segít fejleszteni } \\
\text { az angol nyelvi íráskészségemet (Writing) }\end{array}$ & $3,28 \%$ & $6,56 \%$ & $17,21 \%$ & $43,85 \%$ & $29,10 \%$ \\
\hline $\begin{array}{l}\text { A közösségi média használata segít fejleszteni } \\
\text { az angol nyelvi beszédkészségemet } \\
\text { (Speaking) }\end{array}$ & $4,51 \%$ & $8,61 \%$ & $25,00 \%$ & $37,70 \%$ & $24,18 \%$ \\
\hline $\begin{array}{l}\text { A közösségi média használata segít fejleszteni } \\
\text { az angol nyelvi szöveghallgatási készségemet } \\
\text { (Listening) }\end{array}$ & $3,69 \%$ & $5,33 \%$ & $20,90 \%$ & $36,89 \%$ & $33,20 \%$ \\
\hline $\begin{array}{l}\text { A közösségi média használata segít az angol } \\
\text { nyelvtan elsajátításában (Grammar) }\end{array}$ & $6,15 \%$ & $13,52 \%$ & $27,87 \%$ & $32,38 \%$ & $20,08 \%$ \\
\hline $\begin{array}{l}\text { A közösségi média használata lehetővé teszi, } \\
\text { hogy könnyebben bövítsem az angol nyelvi } \\
\text { szókincsemet (Vocabulary) }\end{array}$ & $2,46 \%$ & $2,87 \%$ & $13,11 \%$ & $43,44 \%$ & $38,11 \%$ \\
\hline $\begin{array}{l}\text { Az angol nyelvtanulás sokkal szórakoztatóbb } \\
\text { lehet a közösségi média alkalmazásokkal }\end{array}$ & $2,05 \%$ & $2,46 \%$ & $17,21 \%$ & $38,93 \%$ & $39,34 \%$ \\
\hline $\begin{array}{l}\text { A közösségi média használata egy jó módja } \\
\text { annak, hogy a tanárok és a diákok angolul } \\
\text { kommunikáljanak }\end{array}$ & $3,28 \%$ & $5,74 \%$ & $25,82 \%$ & $40,57 \%$ & $24,59 \%$ \\
\hline
\end{tabular}

A témában a tanárokról alkotott vélemény az eredmények alapján pozitív, a diákok nagy arányban támogatják a tanárok által IKT-eszközhasználatot az angol órákon és a közösségi média alkalmazásait. A válaszadók nagy többsége gyakrabban szeretné angol nyelven használni a közösségi média alkalmazásait, hogy javítsa angol nyelvtudását, valamint nagy arányban van igény arra, hogy az angoltanárok használjanak friss angol nyelvü anyagokat az internetről, és megtanítsák a diákokat is arra, hogyan keressenek és használjanak online angol nyelvü tananyagokat. A válaszokat megvizsgálva, kijelenthetjük, hogy negyedik hipotézisünk is bebizonyosodott, a diákok pozitívan vélekednek az IKTeszközökről és azok használatáról általában véve és az angol nyelvtanulásban.

2. táblázat: A diákok véleménye az angoltanárok közösségi média alkalmazásáról a nyelvoktatásban

\begin{tabular}{|l|c|c|c|c|c|}
\hline $\begin{array}{l}\text { Milyen mértékben értesz egyet az } \\
\text { alábbi kijelentésekkel? }\end{array}$ & $\begin{array}{l}\text { Egyáltalán nem } \\
\text { éttek egyet }\end{array}$ & $\begin{array}{l}\text { Nem } \\
\text { értek } \\
\text { egyet }\end{array}$ & $\begin{array}{l}\text { Egyet is } \\
\text { étek } \\
\text { meg } \\
\text { nem is }\end{array}$ & Egyetértek & $\begin{array}{l}\text { Nagyon } \\
\text { egyetértek }\end{array}$ \\
\hline $\begin{array}{l}\text { Gyakrabban szeretném angol nyelven } \\
\text { használni a közösségi média } \\
\text { alkalmazásait, hogy javítsam angol } \\
\text { nyelvtudásomat }\end{array}$ & $4,92 \%$ & $9,02 \%$ & $20,90 \%$ & $35,25 \%$ & $29,92 \%$ \\
\hline $\begin{array}{l}\text { Az angoltanárok használjanak friss angol } \\
\text { nyelvü anyagokat az interneten }\end{array}$ & $4,10 \%$ & $2,05 \%$ & $28,28 \%$ & $42,62 \%$ & $22,95 \%$ \\
\hline $\begin{array}{l}\text { Az angoltanárok megtanítanak arra, } \\
\text { hogyan keressek és használjak online } \\
\text { angol nyelvü tananyagokat }\end{array}$ & $10,66 \%$ & $14,34 \%$ & $28,28 \%$ & $34,43 \%$ & $12,30 \%$ \\
\hline $\begin{array}{l}\text { Az angoltanárok gyakran használják a } \\
\text { közösségi média alkalmazásait, hogy az } \\
\text { angol nyelvtanulás sokkal szórakoztatóbb } \\
\text { legyen }\end{array}$ & $13,93 \%$ & $15,16 \%$ & $27,05 \%$ & $31,56 \%$ & $12,30 \%$ \\
\hline $\begin{array}{l}\text { Csatlakozni akarok egy online fórumhoz, } \\
\text { hogy az angol tanulásról beszélhessek a } \\
\text { barátaimmal }\end{array}$ & $22,95 \%$ & $20,08 \%$ & $33,61 \%$ & $18,85 \%$ & $4,51 \%$ \\
\hline $\begin{array}{l}\text { A közösségi média alkalmazásai lehetővé } \\
\text { teszik számomra, hogy hatékonyabban } \\
\text { tanuljak angolul }\end{array}$ & $4,10 \%$ & $3,28 \%$ & $21,31 \%$ & $44,67 \%$ & $26,64 \%$ \\
\hline
\end{tabular}




\begin{tabular}{|l|c|c|c|c|c|}
\hline $\begin{array}{l}\text { Nem szeretem, ha az angoltanárok sok } \\
\text { közösségi média alkalmazást használnak } \\
\text { az oktatásban }\end{array}$ & $15,16 \%$ & $25,00 \%$ & $36,89 \%$ & $14,34 \%$ & $8,61 \%$ \\
\hline $\begin{array}{l}\text { Közösségi média alkalmazások nélkül } \\
\text { akarok angolul tanulni }\end{array}$ & $33,61 \%$ & $31,56 \%$ & $22,95 \%$ & $6,56 \%$ & $5,33 \%$ \\
\hline
\end{tabular}

\section{7. Összegzés}

A kutatás az IKT-eszközökkel való angol nyelvtanulás elemeit helyezte a figyelem központjába. Kijelenthetjük, hogy az első hipotézisünk beigazolódott. Az eredmények azt mutatják, hogy a diákok többet használják az IKT-eszközöket iskolán kívül vagy otthon, kisebb arányban tanulni vagy informálódni, inkább kommunikálni (online kommunikáció a közösségi médián) és szórakozás céljából (zenehallgatás, filmnézés, internetböngészés szórakozás céljából, Facebook, Instagram). Kevesen hoznak létre tartalmakat ezen eszközök segítségével, inkább passzívan használják azokat. A leggyakrabban használt eszköz a mobiltelefon. A válaszadók kétharmada több, mint hat éve használ számítógépet otthon vagy az iskolán kívül.

A második hipotézisünk részben igazolódott be. A vizsgált iskolákban többféle internethozzáférés létezik, a diákok többsége iskolai számítógépen kábeles internetet vagy WiFi-t használ. A diákok nagy hányada soha nem használja az IKT-eszközöket az órákon. Azok a diákok, akik használnak IKTeszközöket tanulás céljából az órákon, túlnyomó többségben napi szinten a saját okostelefonjukat veszik igénybe, ez a válaszadók több, mint felét teszi ki. Az IKT-eszközöket és alkalmazásokat használók legalább hetente egyszer asztali számítógépet internetes hozzáféréssel, multimédia szerkesztési eszközöket pl. PowerPoint, videószerkesztőket, digitális felvevőket, gyakorló szoftvereket, online kvízeket és teszteket is használnak. Napi szinten tanulás céljából online beszélgetnek iskolai dolgokról pl. Facebook, Instant Messenger, Viber, WhatsApp stb., böngészik az internetet, hogy információkat gyüjtsenek, számítógépet használnak a feladatok elvégzéséhez pl. adatok/képek gyüjtéséhez, ezek tárolására, észrevételek dokumentálására.

Megerösítést nyert a harmadik hipotézisünk, mely szerint a diákok használják a felsorolt IKTeszközöket és alkalmazásokat angol nyelvtanulás céljából otthon, az iskolán kívül, illetve az iskolában. Angol nyelven nem kifejezetten tanulásra, inkább passzív vagy receptív tevékenységekre használják az említett alkalmazásokat, letölteni vagy online hallgatni zenét, mobiltelefonon játszani, letölteni filmeket vagy online filmeket nézni, hírek olvasására az interneten, a saját Facebook oldal megtekintésére. Kifejezetten angol nyelvtanulás céljából a fordítókat és online szótárakat részesítik előnyben, illetve az angol nyelven való kommunikációt a közösségi hálózatokon. A felsorolt alkalmazások közül mindegyiket használták már angol nyelvtanulás céljából az iskolában, valamint otthon, otthon jellemzően nagyobb mértékben.

Összességében megállapíthatjuk, hogy a diákok pozitívan állnak az IKT-eszközökkel való angol nyelvtanuláshoz, ami igazolja negyedik hipotézisünket. Az eredmények azt mutatják, hogy a közösségi média használata segít fejleszteni az angol nyelvi olvasási készségüket, bővíti az angol nyelvi szókincsüket, fejleszti az angol nyelvi szöveghallgatási készségüket. Bár ezek inkább a passzív, receptív nyelvi készségeiket fejlesztik, idővel segíthetik az aktív, produktív készségeket is, mint az angol nyelven való beszédet és írást. Igény van a diákok részéről a tanárok útmutatására, hogy a formális tanulásban is alkalmazhassák ezeket az általuk nagyon kedvelt eszközöket és alkalmazásokat, melyeket inkább az informális tanulás területén használják jelenleg.

Kutatásunk eredményei egy nem reprezentatív regionális képet mutatnak a koronavírus járvány kezdetén. Fontos lenne a következőkben részletesebben kutatni ezt a témát, kiterjeszteni több iskolára, hiszen a kialakult járványhelyzet miatt ezen eszközök és alkalmazások használata a mindennapok részévé váltak. 


\section{Irodalomjegyzék}

Chapelle, C. (2010): The spread of computer-assisted language learning. Language Teaching, 43(1), 66-74.

Cox, M. J., Niederhauser, D. S., Castillo, N., McDougall, A. B., Sakamoto, T., Roesvik, S. (2013): Researching IT in education. Journal of Computer Assisted Learning, 29, 474-486, https://doi.org/10.1111/jcal.12035 (2019.11.27.)

Ertmer, P. A., Ottenbreit-Leftwich, A. T. (2010): Teacher technology change: How knowledge, confidence, beliefs, and culture intersect. Journal of Research on Technology in Education, 42(3), 255284.

European Commission. (2010): Digital Agenda for Europe: Key publications [Text]. Digital Single Market - European Commission. https://ec.europa.eu/digital-single-market/en/digital-agenda-europekey-publications (2017.09.05.)

European Commission. (2019): 2nd Survey of Schools: ICT in Education [Text]. Digital Single Market - European Commission. https://ec.europa.eu/digital-single-market/en/news/2nd-survey-schools-icteducation (2019.11.27.)

Golonka, E. M., Bowles, A. R., Frank, V. M., Richardson, D. L., Freynik, S. (2014): Technologies for foreign language learning: A review of technology types and their effectiveness. Computer Assisted Language Learning, 27(1), 70-105.

Griffith, A. (2010): SPSS for Dummies. Wiley Publishing, Inc., Indianapolis, Indiana.

Kern, R., Warschauer, M. (2000): Theory and practice of network-based language teaching. In Networkbased language teaching: Concepts and practice, Cambridge University Press, 1-19.

Schrum, L., Niederhauser, D. S., Strudler, N. (2016): Competencies, Challenges, and Changes: A US Perspective on Preparing Twenty-First Century Teachers and Leaders. In Competencies in teaching, learning and educational leadership in the digital age: Papers from celda 2014, Springer Science+Business Media, 17-32.

Strategia Națională privind Agenda Digitală pentru România 2020. https://www.comunicatii.gov.ro/agenda-digitala-pentru-romania-2020/ (2019.11.27)

Szilágyi, F. (2019): Partium. Reintegráció a magyar-román határvidéken. Károli Gáspár Református Egyetem Állam- és Jogtudományi Kar, Budapest, 9-28.

\section{Szerző}

Ardelean Tímea Krisztina, Pécsi Tudományegyetem (Magyarország), "Oktatás és Társadalom" Neveléstudományi Doktori Iskola. E-mail: timea.ardelean@partium.ro 
